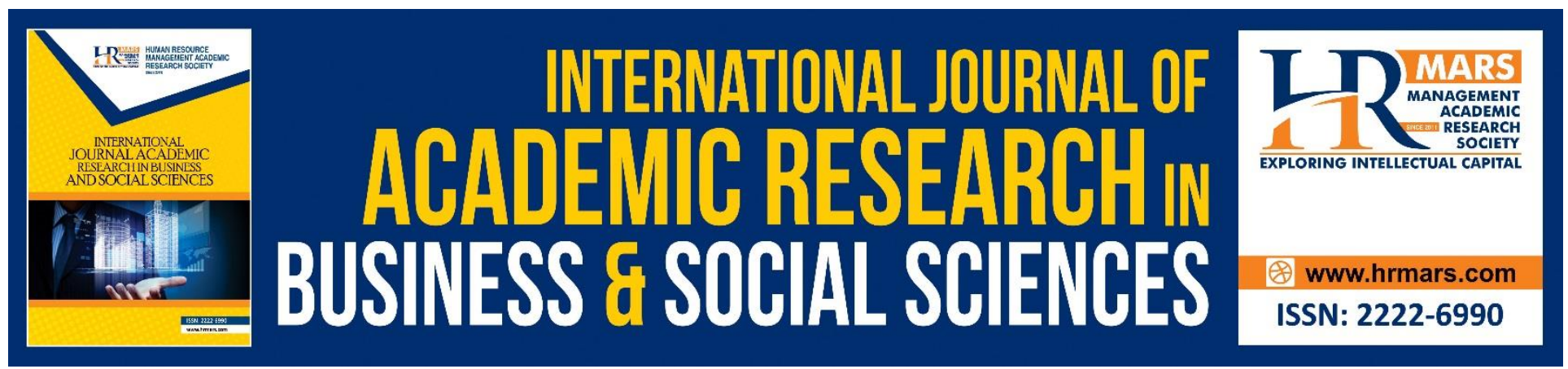

\title{
Impact of Social Media on Malaysia's Election Landscape
}

Nur Nadhirah Binti Ab. Hamid, Safawi Abdul Rahman

To Link this Article: http://dx.doi.org/10.6007/IJARBSS/v8-i9/4590

DOI: $\quad 10.6007 /$ IJARBSS/v8-i9/4590

Received: 17 August 2018, Revised: 24 September 2018, Accepted: 29 Sept 2018

Published Online: 13 October 2018

In-Text Citation: (Hamid \& Rahman, 2018)

To Cite this Article: Hamid, N. N. B. A., \& Rahman, S. A. (2018). Impact of Social Media on Malaysia's Election Landscape. International Journal of Academic Research in Business and Social Sciences, 8(9), 275-284.

\section{Copyright: (C) 2018 The Author(s)}

Published by Human Resource Management Academic Research Society (www.hrmars.com)

This article is published under the Creative Commons Attribution (CC BY 4.0) license. Anyone may reproduce, distribute, translate and create derivative works of this article (for both commercial and non-commercial purposes), subject to full attribution to the original publication and authors. The full terms of this license may be seen at: http://creativecommons.org/licences/by/4.0/legalcode

Vol. 8, No. 9, September 2018, Pg. 275 - 284

Full Terms \& Conditions of access and use can be found at http://hrmars.com/index.php/pages/detail/publication-ethics 


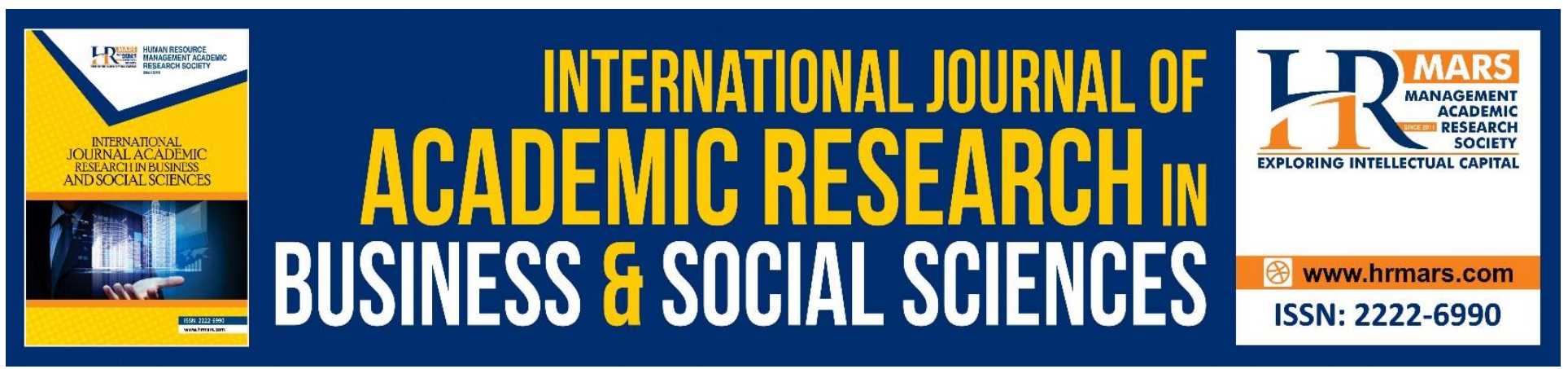

\title{
Impact of Social Media on Malaysia's Election Landscape
}

\author{
Nur Nadhirah Binti Ab. Hamid \\ Post- Graduate Student, Faculty of Information Management Universiti Teknologi MARA (Selangor) \\ Puncak Perdana Campus, 40150 Shah Alam Selangor. \\ Email: nurnadhirah_abhamid@yahoo.com.my \\ Safawi Abdul Rahman \\ Senior Lecturer, Faculty of Information Management, Universiti Teknologi MARA (Selangor) Puncak \\ Perdana Campus, 40150 Shah Alam Selangor. \\ Email: safawi@salam.uitm.edu.my
}

\begin{abstract}
Social media plays an important role as an application that enables users to manage and share the information and knowledge. Due to its effective mean for information management and sharing, lot of information domains are communicated and spread out using social media. With respect to politics and election domain, the use of social media is inevitable. This paper reviews the usage of social media and its impacts towards election landscape in Malaysia especially for 14th general election commenced recently. The purpose of this review is to highlight the role of information disseminated through social media and its impact on Malaysia's Election. Through this highlight, readers capable of acknowledge and consider the role of information and knowledge channel by social media in larger setting. The review adopts the scoping approach in which articles on social media and the use of social media for disseminating political and election information have been gathered. The outcome of review is briefly presented in discussion section.
\end{abstract}

Keywords: Information Management; Social Media; Malaysia General Election

\section{Introduction}

Social media plays an important role as a platform and application that enable users to create and share the information and knowledge with other people. People around the world communicate and share knowledge around the world through social media. It is also increasingly popular and emerging as important information sources (Kim et al, 2012). In this way, social media serves a critical mean for people to use in communicating information and knowledge.

The phenomenon of social media began in the new millennium around 2003 starting with the Myspace. The others social media like Facebook (https://facebook.com), Twitter 
INTERNATIONAL JOURNAL OF ACADEMIC RESEARCH IN BUSINESS AND SOCIAL SCIENCES Vol. 8, No. 9, Sept. 2018, E-ISSN: 2222-6990 @ 2018 HRMARS

(https://twitter.com), Instagram (https://www.instagram.com) and etc. have been introduce since Myspace have gotten the positive feedback from the users. At this time, Facebook, Twitter, Instagram, WhatsApp (https://web.whatsapp.com) are the most popular and top social media that has been used by people in the world. After all, the fast development of social media has caused major changes pertaining the way people find the group of individuals who have same interest, obtain information or knowledge and share the ideas.

There are a lot of information domains that can be communicated and spread out using social media. Healthcare and beauty is one of the domains that are widely shared through social media (Forbes, 2016; Neiger et al. 2012). Tourism is another domain extensively uses social media (Xiang \& Gretzel 2010; Munar \& Jacobsen 2014). Social media is also utilized to share family matters (O'Keeffe, \& Clarke-Pearson 2011; Jelenchick, Eickhoff \& Moreno, 2013). The financial issues and management is another topic mostly shared using social media (Aral, Dellarocas \& Godes, 2013; Sul, Dennis \& Yuan, 2014). Another popular domain that regularly communicated using social media is about politics and election (Muniandy \& Muniandy, 2013; Shirky, 2011). On top of these domains, many other information domains are shared using social media as now social media penetrates all dimensions of human life.

With respect to politics and election, social media plays very critical role and give big impact to the users. This is because in influencing readers, function of social media as propagates the information (Bakshy, E., Rosenn, I., Marlow, C., \& Adamic, L., 2012). As reported by Ye, S., \& Wu, S. F. (2010) social media influence public with issues posted by originator. Based on the previous studies, it showed the influences that obtain from social media has a very significant role in election.

This paper reviews on the usages of social media and its impacts towards election landscape in Malaysia especially for 14 th general election commenced recently. The goal of this review is to highlight the role of information disseminated through social media and its impact on Malaysia's Election Landscape. This paper discusses information and knowledge dissemination using social media in the election in Malaysia. Through this highlight, readers capable of acknowledge and consider the role of information and knowledge channeled by social media in larger setting.

In achieving such a goal, this paper is arranged to include the following sections emphasizing related critical components. The next section briefly reviews about the concept of social media. In the subsequent sub-section, the role of social media in distributing information is presented. The use of social media with respect to disseminating political and election information is presented briefly in sub-section 2 of the literature. The impact of social media on Malaysian political landscape is dedicated in subsection 3 . The methodology that the review follows is justified in section 3 . The discussion follows in section 4 . Section 5 concludes the paper.

\section{Literature Review}

As outlined earlier, this concept paper presents the review of the following components;

\section{The concept of Social Media}

Social media had been conceptualized differently by scholars. As for Kaplan \& Haenlein, (2010), social media is a collection of internet-based applications that develop the ideological and technological 
INTERNATIONAL JOURNAL OF ACADEMIC RESEARCH IN BUSINESS AND SOCIAL SCIENCES Vol. 8, No. 9, Sept. 2018, E-ISSN: 2222-6990 @ 2018 HRMARS

foundations of Web 2.0 and permit the creation and exchange of user-generated content. While according to investopedia.com website, social media is a computer-based technology that facilitates the sharing of ideas and information and the building of virtual networks and communities. By design, social media is internet based and offers users easy electronic communication of personal information and other content, such as videos and photos. Users engage with social media via computer, tablet or smartphone via web-based software or web application, often utilizing it for messaging.

The interesting part of social media is characterized the term user-generated content as refer to different forms of media content, available for public which created by end users in social networking sites synonymous with internet. Thus, by using social media, people not only use online information but also produce unique content themselves (de Zuniga et al, 2014). There are a lot of popular social media platforms preferred by users all over the world. However, choice of social networks vary depends on usage in different countries and demographic. Statisca website (Statisca.com) gives a clear picture about the compilation of the most popular social networks worldwide in year 2018. In previous study by Kaplan \& Haenlein (2010), they that Facebook ruling supreme with over two billion numbers of active users. In Malaysia, Facebook is considered as one of the most social media platforms and this is the reasons why it will be in focus throughout this paper.

A study by New York Times Consumer Insight Group revealed the reasons people sharing information through social media. The study concluded that the motivations for information sharing are desire to share the valuable content to others, to nurture relationships and to support issues they feel strongly about and many more. These reasons give a real impact on society in ways that shape politics, business, education, careers, and more. After all, there are a lot of impacts using social media felt by individuals and groups. This paper will highlight more on disseminating information on politics in Malaysia landscape.

\section{Usage of Social Media}

Many benefits of social media can be obtained for people who using it.From the viewpoint of an individual, the social media platforms can be used for searching information, maintaining contact networks, locating job opportunities and many more. For instance, Facebook which founded in 2004 as an exclusive online student directory limited to Harvard University students and later extended to all universities in the United States. In 2006, Facebook was made available for public use, and since then has observed rapid growth in membership worldwide. Facebook's fundamental features include status, news feed, notifications; these functions enable communication between friends (Lin, J. Y. C., Le, A. N. H., Khalil, S., \& Cheng, J. M. S., 2012). From above statement, every social media has its own benefit to the users' nowadays.

Social media is the most powerful tool for spreading information. It reaches faster and farther than any communication method. It also increases communication and information travel over the world without any borders. According to (Ferguson et al., 2014), the innovation which people can communicate, use and share the information has increased the speed and spread the information. This because the World Wide Web had been changed the way people can communicate. The users are no longer dependent on formal media as nowadays they can use informal media like social media 
INTERNATIONAL JOURNAL OF ACADEMIC RESEARCH IN BUSINESS AND SOCIAL SCIENCES

Vol. 8, No. 9, Sept. 2018, E-ISSN: 2222-6990 @ 2018 HRMARS

and others to interact with others. After all, the power to disseminate the information is in users' hands.

\section{The use of social media for disseminating political and election information}

Social media has been massively used in political and electoral campaigns and therefore become important tool in politics. Pew Research claimed that 62 percent of people obtain news from social media which 18 percent often used. According to Banaij \& Buckingham (2010), by using traditional media young people cannot find the political information predominantly. Because of that, they used social media as a platform to finds information. After all, the voters use social networking sites to gather information about political organizations and candidates.

Social media plays critical role in election where political information is exchanged and distributed massively. On 2008 US campaign, it has been highlighted as an innovation in the field of political communication (Medvic, 2011). Obama's campaign recognized as a prominent innovator in the use of information and communication technologies entirely. This is the first national campaign that used new media technologies and internet besides overshadowed the traditional media (Al Deen and Hendricks, 2012). Through that election, many political organization lessons learnt as they understood the significance of social media in communication strategies recently.

The use of social media in political environment, not only give impact to the political organization and candidates but also the public. This is because the impact of social media on political organizations and candidates, they can directly communicate and interact with public as two ways communication. While the impact for public as voters, they use social media as a platform to share their opinion and to be heard. As a result, specifically the social media can be regarded as a potential platform to engage in politics to attract voters.

\section{Social Media and Malaysian Political Landscape}

There are statistics on the most popular social media used by Malaysian nowadays. Website gs.statcounter.com has been surveyed statistics of the most popular social media that have been used in Malaysia until May 2018. The most popular social media in Malaysia based on the given data from the website are Facebook, YouTube, Twitter, Pinterest, Instagram and Tumblr. Not only wide world statistics but in Malaysia also Facebook had been the most current use in this country. Other than that social media revolution not only happened in America election but also in Malaysia election landscape which stated by (Sern \& Zanuddin, 2014), the social media revolution has transformed the political landscape in Malaysia since the election in 2008 until this year 2018.

\section{The $12^{\text {th }}$ Malaysia General Election}

The $12^{\text {th }}$ election in 2008 has been an historic event because it used a mixture of traditional and contemporary media as alternative to provide information during the weeks of the election campaign (Liow, 2012). Election information like posters, political rallies, small group discussions, Internet campaigning and text messages via mobile phones and many more (Zaitun \& Crump 2005). However, for information seeking that related to politics, the trend has moved to Facebook and Twitter (Ismail \& Hasmah, 2008; Navarria, 2013; Idid \& Chang, 2012). After all, on the 12th election in Malaysia, this poll started to use internet in spreading the political information among public. 
INTERNATIONAL JOURNAL OF ACADEMIC RESEARCH IN BUSINESS AND SOCIAL SCIENCES Vol. 8, No. 9, Sept. 2018, E-ISSN: 2222-6990 @ 2018 HRMARS

\section{The $13^{\text {th }}$ Malaysia General Election}

Malaysian' ex-prime minister mentioned that the general election on 2013 will be the first social media election. He admitted as the spreading growths of social media not only obtain greater openness, but it could be a double-edged sword for his party (UMNO) (Zahid, 2013). In fact, the Internet was absolutely the most influential communication tool among urban dwellers, younger voters and internet-literate voters (Mohamad 2008). As mentioned before, the trend in seeking political information on this 13th election moved to Facebook and Twitter. As proved in this previous article, Sern, T. J., \& Zanuddin, H. (2014), they analyzed that social media especially Facebook, is widely seen to play a important role in the Malaysian 13th general election. The positive relationship between the political parties and public can be achieved if use social media network correctly (Crompton, 2008; Wills \& Reeves, 2007; Zittel, 2007). After all, the positive impact shows that the political parties can influence the public quick by using the spreading growth of social media in this election.

\section{The $14^{\text {th }}$ Malaysia General Election}

BBC News (https://www.bbc.com) stated on 9th May 2018, the opposition, Pakatan Harapan scored historic victory ending the 60 years ruling under Barisan Nasional coalition in General Election landscape in Malaysia. As expected social media have been more influence than ever in this 14th general election according to politicians and analysts who involved in big data. It is expected to be a "Facebook election "year as a popular platform compared to other social media. The star online news stated that for the first time in 14th general election, the political parties in both side used messaging tools frequently. In this 14th election, messaging service WhatsApp and Facebook are the most dominant and effective messaging tools. People get messages and videos on the election almost every day and share with their friends and family chat groups. In a nutshell, the social media that have been used not only reduced the cost of reaching out to the electorate but also changed the landscape of political campaigning compared to the old days. It has proven to be a much cheaper way to campaign.

\section{Impacts of Social Media on Election Landscape in Malaysia}

Based on Malaysia General Elections in year 2008, 2013 and 2018, lot of lesson learnt in the usage of social media and information dissemination. The two segments below are those who have directly impacted by the social media and information dissemination.

\section{Politician}

For politicians that include political leaders and party workers, the social media platforms are useful in their campaign trail during the election seasons. Social media serves as critical mean for the politicians to shape their public image and deliver a sense of transparency to the users by information reached out the public. This online existence of political leaders will show how their interactions with their voters which are very critical part to attract the voters. According to Malaysiandigest.com, on 14th election, about five million young voters who will "on duties" for the first time. The five million taking about 34 percent of the total voters in Malaysia who made up half of the voters totaling 13.3 million. Politicians in Malaysia were already used social media networks to engage and attract the young digital populations who have grown up using the Internet. The Facebook, Twitter, YouTube, news portals and blogs are examples of attractive social media tools which are very trendy, cheap 
INTERNATIONAL JOURNAL OF ACADEMIC RESEARCH IN BUSINESS AND SOCIAL SCIENCES

Vol. 8, No. 9, Sept. 2018, E-ISSN: 2222-6990 (c) 2018 HRMARS

and easy to access that can attract the young voters nowadays. Applying this mean, the politicians can reach more potential voters than ever before.

\section{Voters}

While for the voters, social media enables the information to be obtained by the voters rapidly regardless their locality. Sani (2014) identified that the youngsters get information on their mobile phones or laptops, so it is accessible for them to access information online about the candidates (Alyaa, 2013). They can evaluate and choose the politician based on the seeking given information. Besides that, they have a voice and can share with others about their ideas on political issues using social media. In fact, two general elections in 2008 and 2013 were the proofs that Generation $Y$ is very powerful and can transform the society. Those elections are persistent to the next election in this year, 2018 as young voters account for the biggest ratio to determine the result of the 14th General Election (GE14). After all, the future leaders are chosen based on their young voters. Surely, they are smart, educated and professional which are good in producing excellent Malaysian leaders in the future. After all, social media influence the young voters to choose their own leaders.

\section{Methodology}

The scoping review technique has been adopted in producing this paper. Through this technique, the articles on social media and the use of social media for disseminating political and election information have been gathered and reviewed. Some selected keywords such as social media, election information, information dissemination, Malaysia election landscape and Malaysia general election were used during information retrieval from online database subscribed by Universiti Teknologi MARA, Malaysia and Google Scholar.

\section{Discussion}

The use of social media in politic has changed intensely the way of campaigns run and how Malaysians interacts with their chosen politicians. Due to predominant of social media in politics world make the politicians more concerned to the voters in Malaysia. Besides that, the capability to publish and broadcast the contents must be very careful to manage the candidate's images to the public directly based on rich sets of analytics in real time and at almost no cost. There are many ways of social media can change the Malaysian politics landscape.

Firstly, the way social media can change the politics in Malaysia is the politician can directly contact with voters. This is because the social media tools like Facebook, WhatsApp, and Twitter allow them to speak directly to voters without spending much money. Besides that, with social media also can the politicians can avoid spending money in using traditional method like paid advertising or media. Based on that point, it shows that social media can reduce the budget cost.

The second way that social media can change the politics in Malaysia is advertising without paying for advertising. It is common for politician to publish and disseminate the political campaigns video to the public freely without any cost as not to pay to publish the video using traditional method like on television. With social media, not only politician but also the voters that used social media can disseminate to the others freely without any cost like spreading the campaign through Facebook, YouTube and so on. After all, the politicians can broadcast their message to a wider audience rapidly. 
INTERNATIONAL JOURNAL OF ACADEMIC RESEARCH IN BUSINESS AND SOCIAL SCIENCES Vol. 8, No. 9, Sept. 2018, E-ISSN: 2222-6990 @ 2018 HRMARS

The third way social media can change the election Malaysia Landscape is about controversy. Social media is so powerful in disseminating information and communication. Politicians can use social media to update any political information to the public especially their own supporters. However, social media can turn from a sharing tool to propagate lies, slanders and lustful videos or pictures of political leaders. The ruling and the opposition party used the social media as a tool to slander their opponents. Therefore, the social media can contribute good and bad effects to the politicians and public.

The fourth way social media can change the election because social media is trendy nowadays. It is very effective tools to engage with the young voters. Facebook, Twitter, WhatsApp and other media social have strengthened the younger voters which has an intense impact on elections. Besides there are almost half of the voters are the young voters. The politicians disseminate and broadcast the truthful information to the million peoples especially the young voters which make the young voters easily to believe, evaluate, decide and choose their politicians leaders. The openness of social media gives opportunities to both politicians as well as people of Malaysia to express their opinions. Social media offer a golden opportunity for people to express their views, suggestions and opinions on any topics.

\section{Conclusion}

Social media has become ubiquitous part in our daily life. This paper reviews on the usages of social media and its impacts towards election landscape in Malaysia especially for 14th general election commenced recently. The goal of this review is to highlight the role of information disseminated through social media and its impact on Malaysia's Election Landscape. This paper presents the information that is disseminated using social media influence the election in Malaysia. Through this highlight, readers capable of acknowledge and consider the role of information and knowledge channel by social media in larger setting. After all, as a public sphere tool, social media is a crucial component for the political community as the space for politicians and public in voicing their views to influence the political institutions of society in Malaysia.

\section{References}

Alyaa, A. (2013). Social media crucial in election campaign. Free Malaysia Today, 19 April. https://www.freemalaysiatoday.com/category/nation/ 2013/04/19/social-media-crucial-inelection-campaign/ (accessed 20 April 2013).

Aral, S., Dellarocas, C., \& Godes, D. (2013). Introduction to the special issue - social media and business transformation: a framework for research. Information Systems Research, 24(1), 313.

Bakshy, E., Rosenn, I., Marlow, C., \& Adamic, L. (2012, April). The role of social networks in information diffusion. In Proceedings of the 21st international conference on World Wide Web (pp. 519-528). ACM.

Banaij, S. \& Buckingham, D.(2010).Young People, the Internet, and Civic Participation: An Overview of Key Findings from the CivicWeb Project, International Journal of Learning and media,2 (1), pp. 1-24.

Crompton, J. (2008). Mixing friends with politics: a functional analysis of '08 Presidential candidates social networking profiles. Paper presented at the Annual Meeting of the National Communication Association 94th Annual Convention, San Diego, California. 
INTERNATIONAL JOURNAL OF ACADEMIC RESEARCH IN BUSINESS AND SOCIAL SCIENCES

Vol. 8, No. 9, Sept. 2018, E-ISSN: 2222-6990 @ 2018 HRMARS

Ferguson, C., Inglis, S. C., Newton, P. J., Cripps, P. J. S., Macdonald, P. S., \& Davidson, P. M. (2014). Social media: A tool to spread information: A case study analysis of Twitter conversation at the Cardiac Society of Australia \& New Zealand 61st Annual Scientific Meeting 2013. Collegian, 21(2), 89-93. https://doi.org/10.1016/i.colegn.2014.03.002

Forbes, K. (2016). Examining the Beauty Industry's Use of Social Influencers. ELON Journal, 78.

Gabbay, S. M., \& Leenders, R. T. (1999). CSC: The structure of advantage and disadvantage. In Corporate social capital and liability (pp. 1-14). Springer, Boston, MA.

Gil de Zúñiga, H., Molyneux, L., \& Zheng, P. (2014). Social media, political expression, and political participation: Panel analysis of lagged and concurrent relationships. Journal of Communication, 64(4), 612-634.

Gordon, K. (n.d.). Topic: Social media. Retrieved from https://www.statista.com/topics/1164/socialnetworks/

Hallikainen, P. (2015). Why people use social media platforms: Exploring the motivations and consequences of use. In From Information to Smart Society (pp. 9-17). Springer, Cham.

Idid, S. A., \& Chang, P. K. (2012). The media and public agenda among the Malay and Chinese communities during the 2008 Malaysian General Elections. Asian Social Science, 8(5), $107-$ 115. doi: $10.5539 / a s s . v 8 n 5 p 107$

Jelenchick, L. A., Eickhoff, J. C., \& Moreno, M. A. (2013). “Facebook depression?” Social networking site use and depression in older adolescents. Journal of Adolescent Health, 52(1), 128-130.

Kaplan, A. M., \& Haenlein, M. (2010). Users of the world, unite! The challenges and opportunities of Social Media. Business horizons, 53(1), 59-68.

Kim, K. S., St, N. P., Wi, M., Ching, S., \& Sin, J. (2012). Use of social media in different contexts of information seeking : effects of sex and problem solving style.

Lin, J. Y. C., Le, A. N. H., Khalil, S., \& Cheng, J. M. S. (2012). Social media usage and work values: The example of Facebook in Taiwan. Social Behavior and Personality: an international journal, 40(2), 195-200.

Liow, J. C. (2012). Malaysia's March 2008 general election: Understanding the new media factor. The Pacific Review, 25(3), 293-315. doi: 10.1080/09512748.2012.685096

Medvic, S. (2011) "New directions in campaigns and elections" 1st edition, Routledge, United States of America, New York

Mohamad, M. (2008), 'Malaysia - Democracy and the End of Ethnic Politics,' Australian Journal of International Affairs, vol. 62, no. 4, pp. 441-459.

Muntean, A. (2015). The Impact of Social Media Use of Political Participation, (August), 1-90. Retrieved from http://pure.au.dk/portal-asb student/files/90378581/The_Impact_of_Social_Media_on_Political_Participation.pdf

Munar, A. M., \& Jacobsen, J. K. S. (2014). Motivations for sharing tourism experiences through social media. Tourism management, 43, 46-54.

Muniandy, L., \& Muniandy, B. (2013). The impact of social media in social and political aspects in Malaysia: An overview. International journal of humanities and social science, 3(11), 71-76.

Navarria, G. (2013). Malaysia after the Election: A paradigm shift? Retrieved from http://www.opendemocracy.net/giovanni-navarria/malaysia-after-election-paradigm- shift

Neiger, B. L., Thackeray, R., Van Wagenen, S. A., Hanson, C. L., West, J. H., Barnes, M. D., \& Fagen, M. C. (2012). Use of social media in health promotion: purposes, key performance indicators, and evaluation metrics. Health promotion practice, 13(2), 159-164.

Noor Al-Deen, H. (2012) "Social media: usage and impact" Lexington Books, Lanham 
INTERNATIONAL JOURNAL OF ACADEMIC RESEARCH IN BUSINESS AND SOCIAL SCIENCES

Vol. 8, No. 9, Sept. 2018, E-ISSN: 2222-6990 @ 2018 HRMARS

O'Keeffe, G. S., \& Clarke-Pearson, K. (2011). The impact of social media on children, adolescents, and families. Pediatrics, 127(4), 800-804.

Sani, M. A. M. (2014). The social media election in Malaysia: The 13th general election in 2013. Kajian Malaysia, 32(2), 123.

Sern, T. J., \& Zanuddin, H. (2014). Malaysia's 13th General Election : Political Communication and Public Agenda in Social Media, 1(2), 73-89.

Shirky, C. (2011). The political power of social media: Technology, the public sphere, and political change. Foreign affairs, 28-41.

Sul, H. K., Dennis, A. R., \& Yuan, L. I. (2014, January). Trading on Twitter: The financial information content of emotion in social media. In System Sciences (HICSS), 2014 47th Hawaii International Conference on (pp. 806-815). IEEE.

Wills, D., \& Reeves, S. (2007). Facebook as a political weapon: Information in social networks. British Politics 4(2), 265-281.

Xiang, Z., \& Gretzel, U. (2010). Role of social media in online travel information search. Tourism management, 31(2), 179-188.

Ye, S., \& Wu, S. F. (2010, October). Measuring message propagation and social influence on Twitter. com. In International Conference on Social Informatics (pp. 216-231). Springer, Berlin, Heidelberg.

Zahid, S. J. (2013). Najib: Election 2013 first social media election, The Malaysian

Insider. Retrieved from http://www.themalaysianinsider.com/malaysia/article/najib-election-2013first- social-media-election

Zaitun, A.B. \& Crump, B. (2005), 'Overcoming the Digital Divide: A Proposal on How Institutions of Higher Education Can Play a Role,' Malaysian Online Journal of Instructional Technology, Vol. 2(1). http://unpan1.un.org/intradoc/groups/public/ documents/apcity/unpan040684.pdf. Retrieved on 27 Jun. 2018.

Zittel, T. (2007). Lost in technology? Political parties and online-campaigning in mixed member electoral systems. Paper presented at the ECPR General Conference, Pisa, Italy. 